\title{
Hubungan antara Kebiasaan sarapan dengan Status Gizi pada siswa SMP Negeri 5 Banyuwangi
}

\section{Relationship between Habits of Breakfast and Nutritional Status of Students in SMP Negeri 5 Banyuwangi}

\author{
Sheila Monica Kelly Amalia ${ }^{1}$, Merryana Adriani ${ }^{2}$
}

\begin{abstract}
ABSTRAK
Latar Belakang: Meningkatnya kegemukan atau obesitas sebesar 14,8 persen menurut Riskesdas tahun 2018 perlu menjadi perhatian publik. Obesitas pada remaja dapat mengakibatkan tingginya risiko penyakit degeneratif. Salah satu penyebab obesitas yakni kebiasaan sarapan yang sering ditinggalkan.

Tujuan: Penelitian ini bertujuan menganalisis hubungan antara kebiasaan sarapan dengan status gizi pada siswa SMP Negeri 5 Banyuwangi.

Metode: Jenis penelitian ini merupakan penelitian observasional desain cross sectional. Besar sampel penelitian ini adalah 37 siswa kelas 7 SMP Negeri 5 Banyuwangi. Cara pengambilan sampel dengan Proportionate Stratified Random Sampling. Pengambilan data dilakukan dengan wawancara menggunakan kuesioner food recall 3×24 jam, kuesioner kebiasaan sarapan, dan status gizi ditentukan berdasarkan pengukuran IMT/U. Analisis data dilakukan untuk mengetahui distribusi frekuensi dan presentase tiap variabel yang diteliti. Analisis statistik yang digunakan adalah uji regresi.

Hasil: Hasil penelitian menunjukkan sebagian besar siswa memiliki kebiasaan sarapan baik (91,9\%), status gizi normal (72,9\%). Hasil uji regresi menunjukkan bahwa adanya hubungan kebiasaan sarapan dengan status gizi $(p=0,049)$.

Kesimpulan: Kebiasaan sarapan berhubungan dengan status gizi siswa SMP Negeri 5 Banyuwangi.
\end{abstract}

Kata kunci: kebiasaan sarapan, status gizi, remaja

\section{ABSTRACT}

Background: The increase prevalence in obesity by 14.8 percent according to Riskesdas 2018 needs to be a public concern. Obesity in adolescents can result in a high risk of degenerative diseases in later life. One cause of obesity is breakfast habits that are often left abandoned.

Objective: This study was aimed to analyze the relationship between habits of breakfast and nutritional status of students in SMP Negeri 5 Banyuwangi.

Method: This study was an observational study using design of cross sectional. The sample size of this study was 37 seventh grade students of SMP Negeri 5 Banyuwangi. The method of sampling was Proportionate Stratified Random Sampling. The data were collected by interviewing using food recall $3 \times 24$ hours, habits of breakfast questionnaire, and nutritional status was determined based on BMI for age measurements. Data analysis was performed to determine the frequency distribution and the percentage of each variable studied. The statistical analysis used is a regression test.

Results: The results showed that most students had good habits of breakfast (91.9\%), normal nutritional status (72.9\%). The regression test results show that there was a correlation between habits of eating breakfast and nutritional status $(p=0.049)$.

Conclusion: Breakfast habits related to nutritional status of students of SMP Negeri 5 Banyuwangi.

Keywords: breakfast habits, nutritional status, adolescents

*Koresponden:

sheilamonica12@yahoo.com

${ }^{1}$ Departemen Gizi Kesehatan, Fakultas Kesehatan Masyarakat-Universitas Airlangga 


\section{PENDAHULUAN}

Masalah yang dapat terjadi terkait status gizi yakni status gizi kurang dan status gizi lebih atau obesitas. Menurut Riskesdas tahun 2018 prevalensi obesitas meningkat menjadi 14,8 persen dari tahun 2013. Provinsi jawa timur menempati urutan ke-15 tertinggi di Indonesia ${ }^{1}$. Berdasarkan hasil pemeriksaan obesitas menurut jenis kelamin, kecamatan, dan puskesmas Provinsi Jawa Timur tahun 2017 menunjukkan bahwa prevalensi obesitas pada laki-laki dan perempuan sebesar 16,25 persen. Berdasarkan hasil pemeriksaan obesitas menurut jenis kelamin pada Kabupaten Banyuwangi tahun 2017 menyatakan bahwa prevalensi obesitas pada laki-laki sebesar 54,94 persen, sedangkan pada perempuan sebesar 56,21 persen ${ }^{2}$. Obesitas pada usia dini memiliki potensi lebih terhadap faktor risiko kesehatan yang berlanjut pada usia senja ${ }^{3}$.

Salah satu faktor yang dapat berpengaruh terhadap status gizi ialah kebiasaan sarapan. Asupan energi sarapan yang sehat menyumbang sebesar $15-30 \%$ dari anjuran kebutuhan gizi dalam sehari. ${ }^{4}$ Kebutuhan gizi yang terpenuhi pada anak sekolah berperan penting mendukung pertumbuhan dan perkembangannya. Kebutuhan gizi pada anak usia sekolah dapat meningkat dengan pesat sehingga asupan gizi yang dikonsumsi setiap hari dapat berdampak terhadap kehidupan remaja. Kekurangan maupun kelebihan gizi dapat mempengaruhi aspek fisik dan mental anak. ${ }^{5}$ Sarapan menyumbangkan energi dan kebutuhan zat gizi yang dapat mendukung aktivitas harian dan juga mempengaruhi status gizi anak. Anak yang mempunyai kebiasaan melewatkan sarapan berisiko tiga kali lebih tinggi mengonsumsi makanan ringan dan sulit mengontrol nafsu makan sehingga berdampak mengalami kejadian obesitas. ${ }^{6}$

Berdasarkan observasi awal pada Agustus 2018 yang menyatakan bahwa 7 dari 10 siswa kelas 7 SMP Negeri 5 Banyuwangi mengalami kejadian pingsan pada saat melaksanakan upacara pagi di sekolah dengan alasan tidak sarapan. Masalah tersebut perlu menjadi perhatian dan tidak dapat dikesampingkan mengingat remaja sekolah mempunyai hak untuk mendapat pendidikan dengan baik. Rumusan masalah yang dapat diambil dari permasalahan tersebut adalah apakah terdapat hubungan antara kebiasaan sarapan dengan status gizi pada siswa SMP Negeri 5 Banyuwangi? Tujuan penelitian ini adalah menganalisis hubungan antara kebiasaan sarapan dengan status gizi pada siswa SMP Negeri 5 Banyuwangi. Manfaat dari penelitian ini yaitu dapat memberi informasi kepada remaja mengenai pentingnya kebiasaan sarapan dalam memenuhi kebutuhan gizi dan sebagai masukan dalam pengelolaan makanan sehat di kantin sekolah.

\section{METODE}

Jenis penelitian ini menggunakan penelitian observasional dengan desain cross sectional. Data variabel pada penelitian ini yakni variabel terikat (kebiasaan sarapan) dan variabel bebas (status gizi). ${ }^{7}$

Populasi dalam penelitian ini yaitu siswa dan siswi kelas 7 SMP Negeri 5 Banyuwangi yang berjumlah 220 siswa. Pengambilan sampel penelitian ini menggunakan Rumus Slovin didapatkan sampel penelitian berjumlah 37 siswa. Teknik pengambilan sampel menggunakan proportionate stratified random sampling. Jumlah sampel diambil sebanyak 37 siswa kelas 7 yang terdiri dari 6 kelas yakni kelas A dengan 6 sampel, kelas B diambil 6 sampel, kelas C diambil 7 sampel, kelas D diambil 6 sampel, kelas E diambil 6 sampel, dan kelas F diambil 6 sampel. Lokasi dan waktu penelitian ini dilaksanakan pada bulan Oktober $2018 \mathrm{di}$ SMP Negeri 5 Banyuwangi. Adapun beberapa kriteria inklusi dalam penelitian ini yaitu siswa laki-laki atau perempuan kelas 7, dalam keadaan sehat, bersedia menjadi responden atau subjek penelitian, dapat berkomunikasi dengan baik, hadir pada saat dilakukan pengambilan data.

Cara pengambilan data dalam penelitian ini yaitu data identitas dan jenis kelamin responden diperoleh dari wawancara dengan kuesioner kepada responden, umur responden dapat diketahui dari kuesioner data diri yang berisi umur responden saat penelitian dilakukan, kebiasaan sarapan dengan wawancara menggunakan kuesioner kebiasaan sarapan, status gizi siswa diperoleh dari pengukuran tinggi badan dengan microtoise dan berat badan siswa diukur dengan timbangan. Pengumpulan data terdiri dari kebiasaan sarapan dengan metode wawancara menggunakan kuesioner food recall 3 hari secara tidak berurutan selama satu minggu dan kuesioner kebiasaan sarapan pengembangan dari penelitian lain yang berisi 12 pertanyaan pilihan ganda untuk mengukur kebiasaan sarapan responden. ${ }^{8}$ Untuk pertanyaan dengan 5 pilihan jawaban: Jawaban A skor 4, jawaban B skor 3 , jawaban C skor 2, jawaban $D$ skor 1 , dan jawaban $E$ skor 0 , serta untuk pertanyaan dengan 2 pilihan jawaban: jawaban $A$ skor 4, dan jawaban B skor 2. Skor tertinggi adalah 48 dan skor terendah adalah 12. Kemudian skor diubah menjadi bentuk persen dan dilakukan pengkategorian dengan hasil baik $>55 \%$ jawaban benar dan kurang $\leq 55 \%$ jawaban benar. ${ }^{9}$ Status gizi diperoleh dari data tinggi badan dan berat badan responden, selanjutnya dihitung IMT nya serta dikategorikan berdasarkan z-score Indeks Massa Tubuh menurut Umur (IMT/U). ${ }^{10}$

Analisis data dilakukan untuk mengetahui distribusi frekuensi dan presentase tiap variabel yang diteliti. Variabel yang diteliti meliputi jenis kelamin, usia, pengetahuan gizi, kebiasaan sarapan, dan status gizi siswa. Penyajian data analisis ini dalam bentuk tabel distribusi frekuensi. Untuk membuktikan hipotesis dalam penelitian ini, dilakukan uji normalitas yaitu uji kolmogorov smirnov untuk mengetahui distribusi data. Analisis statistik yang digunakan yaitu dengan uji regresi. Penelitian ini telah mendapat persetujuan dari Komisi Etik Penelitian Kesehatan Fakultas Kesehatan Masyarakat Universitas Airlangga dengan nomor kaji etik 488-KEPK pada tanggal 13 Agustus 2018. 


\section{HASIL DAN PEMBAHASAN}

Hasil penelitian menunjukkan bahwa usia siswa kelas 7 SMP Negeri Banyuwangi adalah 12, 13, dan 14 tahun. Karakteristik usia responden mayoritas siswa berusia 13 tahun berjumlah 22 siswa (59,46\%), sedangkan siswa yang berusia 12 tahun berjumlah 13 siswa (35,14\%), dan siswa yang berusia 14 tahun berjumlah 2 siswa (5,40\%). Sedangkan pada karakteristik jenis kelamin siswa didominasi oleh perempuan yaitu sebanyak 24 siswa $(64,86 \%)$ daripada laki-laki yaitu 13 siswa (35,14\%).

Berdasarkan tabel 2 yang menunjukkan sebagian besar kebiasaan sarapan siswa dengan kategori baik sebanyak 24 (91,9\%) dari seluruh responden 37 siswa. Pada tabel pertanyaan kebiasaan sarapan ratarata (mean) secara keseluruhan dapat diketahui kebiasaan sarapan dari siswa SMP Negeri 5 Banyuwangi tergolong baik ditunjukkan dengan nilai rata-rata (mean) jawaban sebesar 2,88 .

Tabel 1. Karakteristik responden berdasarkan jenis kelamin dan usia siswa SMP Negeri 5 Banyuwangi

\begin{tabular}{|c|c|c|}
\hline Karakteristik & Jumlah (n) & Persentase (\%) \\
\hline \multicolumn{3}{|l|}{ Jenis Kelamin } \\
\hline - Laki-laki & 13 & 35,14 \\
\hline - Perempuan & 24 & 64,86 \\
\hline \multicolumn{3}{|l|}{ Usia } \\
\hline - 12 tahun & 13 & 35,14 \\
\hline - 13 tahun & 22 & 59,46 \\
\hline - $\quad 14$ tahun & 2 & 5,40 \\
\hline Total & 37 & 100 \\
\hline
\end{tabular}

Tabel 2. Kebiasaan Sarapan siswa SMP Negeri 5 Banyuwangi

\begin{tabular}{lcc}
\hline \multicolumn{1}{c}{ Kebiasaan Sarapan } & Jumlah $(\mathbf{n})$ & Persentase (\%) \\
\hline Kurang & 3 & 8,1 \\
\hline Baik & 34 & 91,9 \\
\hline Total & 37 & 100,0 \\
\hline
\end{tabular}

Hasil kuesioner kebiasaan sarapan diketahui pada indikator ketersediaan sarapan siswa dapat diketahui kemungkinan yang dapat terjadi yaitu sebagian besar siswa tidak biasa sarapan dengan alasan tidak tersedianya sarapan di rumah. Dengan demikian siswa cenderung lebih memilih membeli makanan di kantin sekolah. Tidak tersedianya sarapan di rumah dan keterbatasan waktu yang dekat dengan jadwal masuk sekolah juga dapat menyebabkan siswa memilih mengkonsumsi makanan ringan. Kebiasaan siswa pada era modern ini yaitu terbiasa makan makanan ringan daripada makan makanan seimbang dan sehat. ${ }^{11}$ Kebiasaan ini dapat menjadi risiko bagi siswa terutama untuk jangka panjang terhadap penyakit. Selain itu, adapun kemungkinan lain pada indikator ketersediaan sarapan yang dapat terjadi yaitu siswa yang sering sarapan dengan membawa bekal yang disediakan dari rumah atau beli bekal di kantin sekolah maupun diluar sekolah pada saat sebelum berangkat untuk dikonsumsi di kelas ataupun dimakan saat istirahat. Sedangkan indikator teman sebaya siswa dapat menunjukkan pengaruh siswa terhadap teman sebaya dan lingkungan sekitarnya terutama pada saat membeli atau mengonsumsi makanan.

Selanjutnya indikator uang saku pada kuesioner kebiasaan sarapan siswa menunjukkan bahwa mayoritas siswa mendapakan uang saku sekolah dari orang tua/wali namun kebanyakan siswa tidak menghabiskan semua uang saku untuk membeli atau mengonsumsi makanan di sekolah. Hal tersebut tentu menjadikan kebiasaan yang baik bagi siswa yaitu siswa dapat menabung dari siswa uang saku sekolah. Namun masih terdapat siswa yang menghabiskan seluruh uang sakunya untuk membeli makanan di sekolah. Hal ini dapat terjadi kemungkinan karena uang saku yang diberikan hanya cukup untuk membeli makanan di sekolah saja atau siswa terbiasa mengonsumsi makanan ringan dalam jumlah yang banyak.

Indikator jarak tempuh ke sekolah pada kuesioner kebiasaan sarapan siswa dapat diketahui lebih banyak siswa yang berjarak dekat dengan sekolah dan aksesibilitas dari rumah ke sekolah mudah. Hal tersebut dapat terjadi karena sekolah terletak di pusat Kabupaten Banyuwangi dan mudah dijangkau oleh penduduk. Namun masih terdapat siswa yang jarak tempuh dari rumah ke sekolahnya jauh atau aksesibilitas ke sekolah sulit. Hal tersebut dapat terjadi kemungkinan karena SMP Negeri 5 Banyuwangi merupakan sekolah favorit di Kabupaten Banyuwangi sehingga adapun siswa yang bersedia dan rela untuk menempuh jarak yang jauh untuk mendapatkan pendidikan terbaik.

Sebagian besar jenis makanan sarapan yang paling sering dikonsumsi pada saat sarapan adalah adalah nasi dan ayam $(29,8 \%)$ serta nasi, ikan dan sayur (13,5\%). Berdasarkan data Badan Pusat Statistik ratarata konsumsi beras per kapita seminggu yang berasal dari nasi putih meningkat 67 persen dari Maret 2011 ke Maret 2018. Pola konsumsi nasi putih pada tahun 20112018 secara umum cenderung meningkat, karena nasi putih merupakan makanan pokok yang dikonsumsi setiap hari. Selain itu, pola konsumsi ikan dan udang segar, daging ayam ras/kampung juga mengalami peningkatan. Dari tahun 2014-2018 peningkatan terbanyak pada konsumsi ikan dan udang segar naik sebesar $0,05 \mathrm{~kg}$, dan untuk daging ayam ras/kampung naik sebesar $0,035 \mathrm{~kg} .{ }^{12}$

Makanan sumber protein hewani yang paling sering dikonsumsi siswa saat sarapan adalah ayam, ikan dan telur. Pada umumnya ayam disajikan atau diolah dengan cara digoreng, sedangkan ikan dan telur juga biasanya diolah dengan cara digoreng baik diceplok maupun didadar. Makanan sumber protein nabati yang sering dikonsumsi siswa saat sarapan adalah tahu dan tempe, yang biasanya diolah dengan cara digoreng, ditumis dan disemur. Makanan sumber vitamin dan mineral yang sering dikonsumsi saat sarapan adalah sayuran yang biasanya diolah dengan cara dikukus dan ditumis. Sedangkan untuk buah-buahan sangat sedikit dan masih jarang siswa yang mengonsumsi. Buah yang dikonsumsi siswa adalah pisang, apel, jeruk, anggur, namun masih jarang dikonsumsi siswa saat sarapan. Sedangkan minuman yang paling banyak dikonsumsi 
pada saat sarapan adalah teh manis $(8,1 \%)$. Hal tersebut dapat terjadi karena sudah menjadi kebiasaan siswa tersebut dan kemungkinan minuman tersebut selalu disediakan oleh orangtua atau wali siswa tersebut ketika di rumah. Jenis minuman lain yang dikonsumsi siswa pada saat sarapan adalah susu. Namun susu perlu dikombinasikan dengan makanan lain.

Sebagian besar frekuensi sarapan murid adalah 1-2 kali/minggu atau jarang (40,54\%). Sedangkan siswa yang selalu sarapan setiap hari hanya sebesar $24,32 \%$. Sebagian besar siswa yang jarang sarapan beralasan tidak sempat, tidak ada yang menyediakan dan tidak selera karena tidak terbiasa. Biasanya siswa yang jarang sarapan dengan alasan tidak sempat cenderung membeli makanan atau jajanan di kantin sekolah pada saat sebelum masuk kelas, sedangkan sebagian siswa lainnya hanya mengonsumsi jajan saat istirahat saja untuk mengganjal perut agar tidak lapar. Sebaiknya jika tidak sempat sarapan, orang tua atau wali siswa dapat membawakan bekal makanan kepada anak.

Sebagian besar kontribusi sarapan terhadap kecukupan gizi dengan kategori cukup yaitu karbohidrat $(83,78 \%)$, dan protein $(72,97 \%)$, serta lemak $(83,78)$. Sedangkan kontribusi sarapan terhadap kecukupan gizi dengan kategori kurang yaitu karbohidrat $(16,22 \%)$, protein $(27,03 \%)$, dan lemak (16,22\%). Kontribusi karbohidrat dalam sarapan dengan kategori kurang sebanyak 6 siswa, dan kontribusi protein yang kurang sebanyak 10 siswa, serta kontribusi lemak yang kurang berjumlah 6 siswa. Jika dibandingkan dengan data jenis sarapan dapat diketahui bahwa siswa yang kontribusi zat gizi makro dalam sarapannya kurang adalah siswa yang mengonsumsi teh manis, susu, susu dan jus. Sehingga dapat disimpulkan bahwa mengonsumsi minuman tersebut pada saat sarapan tidak dapat memenuhi asupan gizi yang cukup dan dapat menyebabkan siswa cepat lapar saat di kelas bahkan dapat mengganggu konsentrasi belajar karena lapar. Sebaiknya tambahkan makanan pokok yang dapat dibawa dengan mudah seperti roti atau bekal makanan bergizi.

Kurangnya gizi di waktu pagi hari akan mengakibatkan anak merasa lemas dan tidak bersemangat di sekolah, dan dengan kemungkinan terburuknya yaitu anak mengalami pusing karena kurangnya gula dalam darah dan mengalami kejadian pingsan saat upacara atau beraktivitas di luar kelas. Kekurangan karbohidrat secara terus-menerus dapat menyebabkan berat badan menurun dan tubuh menjadi rentan terhadap penyakit. Remaja yang kurus atau kurang energi kronis (KEK) akan berdampak buruk terhadap kesehatannya seperti gangguan hormon serta meningkatnya risiko terkena berbagai penyakit infeksi. Tindakan pencegahan agar remaja tidak mengalami kurang energi kronis adalah dengan mengonsumsi makanan gizi seimbang.

Tabel 4. Status gizi siswa SMP Negeri 5 Banyuwangi

\begin{tabular}{lcc}
\hline \multicolumn{1}{c}{ Status gizi } & Jumlah $(\mathbf{n})$ & Persentase (\%) \\
\hline Sangat kurus & 1 & 2,7 \\
\hline Kurus & 5 & 13,5 \\
\hline Normal & 27 & 73,0 \\
\hline Gemuk & 3 & 8,1 \\
\hline Obesitas & 1 & 2,7 \\
\hline Total & 37 & 100,0 \\
\hline
\end{tabular}

Kekurangan protein juga menyebabkan tubuh menjadi rentan sakit, dan kehilangan massa otot. Protein merupakan zat gizi pembangun sel tubuh jadi akan sangat penting untuk memenuhi zat gizi tersebut. Kehilangan massa otot akan menyebabkan kita mudah lelah dan sulit bergerak. Kekurangan lemak mengakibatkan tubuh sering merasa kedinginan karena simpanan lemak dibawah jaringan kulit yang sedikit. Tubuh juga menjadi cepat lapar dan dapat menganggu kesehatan jantung dan pembuluh darah. ${ }^{13}$

Status gizi adalah suatu ukuran mengenai kondisi tubuh seseorang yang dapat diketahui dari makanan yang dikonsumsi dan penggunan zat-zat gizi dalam tubuh. Penilaian status gizi dengan cara antropometri yaitu dengan mengukur tinggi badan dengan microtoise dan mengukur berat badan dengan timbangan. Pengukuran antropometri (berat badan dan tinggi badan) dengan menggunakan IMT $=\mathrm{BB}(\mathrm{kg}) / \mathrm{TB}^{2}$ $\left(\mathrm{m}^{2}\right)$. Kemudian dikategorikan berdasarkan z-score Indeks Massa Tubuh menurut Umur (IMT/U).

Tabel 3. Pertanyaan Kuesioner Kebiasaan Sarapan siswa SMP Negeri 5 Banyuwangi

\begin{tabular}{|c|c|c|c|c|c|c|c|}
\hline \multirow[t]{2}{*}{ Pertanyaan } & \multicolumn{5}{|c|}{ Skor Jawaban } & \multirow[t]{2}{*}{ Mean } & \multirow[t]{2}{*}{ Kategori } \\
\hline & 0 & 1 & 2 & 3 & 4 & & \\
\hline Saya sarapan setiap hari & 5 & 10 & 7 & 6 & 9 & 2,11 & Normal \\
\hline Saya sarapan tepat waktu di pagi hari & 10 & 1 & 1 & 15 & 10 & 2,38 & Normal \\
\hline Saya terbiasa membawa bekal ke sekolah & 0 & 0 & 28 & 0 & 9 & 2,49 & Normal \\
\hline Saya biasa membawa bekal bergizi & 12 & 14 & 1 & 1 & 9 & 1,49 & Jarang \\
\hline Saya membeli makanan di kantin sekolah & 3 & 15 & 6 & 6 & 7 & 1,97 & Sering \\
\hline Saya terbiasa membeli makanan dengan teman & 1 & 4 & 1 & 28 & 3 & 2,76 & Baik \\
\hline Saya terbiasa membeli makanan yang sama dengan teman & 0 & 0 & 15 & 0 & 22 & 3,19 & Sangat baik \\
\hline Saya terbiasa menentukan makanan yang akan dibeli & 0 & 0 & 3 & 0 & 34 & 3,84 & Sangat baik \\
\hline Saya mendapatkan uang saku sekolah & 0 & 0 & 1 & 0 & 36 & 3,89 & Sangat baik \\
\hline Saya menggunakan uang saku sekolah untuk membeli makanan & 0 & 0 & 8 & 0 & 29 & 3,57 & Sangat baik \\
\hline Rumah/tempat tinggal saya dengan sekolah berjarak dekat & 2 & 1 & 4 & 7 & 23 & 3,30 & Sangat baik \\
\hline Aksesibilitas (seperti jalan, transportasi dll) ke sekolah mudah & 0 & 0 & 7 & 0 & 30 & 3,62 & Sangat baik \\
\hline Kebiasaan Sarapan & & & & & & 2,88 & Baik \\
\hline
\end{tabular}


Berdasarkan tabel 3 diperoleh data siswa dengan hasil paling banyak yaitu status gizi normal sebanyak 27 siswa (73\%), sedangkan status gizi kurus sebanyak 5 orang $(13,5 \%)$. Ketidakseimbangan gizi dapat berdampak pada gangguan kesehatan jangka panjang. Kelebihan gizi pada siswa dapat menimbulkan risiko penyakit degeneratif, gangguan fungsi pernapasan, dan penyakit kardiovaskular. Sedangkan kekurangan gizi pada siswa dapat meningkatkan risiko terhadap penyakit infeksi. ${ }^{14}$

Berdasarkan tabel 4 dapat diketahui bahwa data didominasi oleh siswa yang terbiasa sarapan dengan baik dan berstatus gizi normal $(70,3 \%)$, dan siswa yang terbiasa sarapan dengan baik dan berstatus gizi kurus $(8,1 \%)$, serta siswa yang terbiasa sarapan dengan baik dan berstatus gizi gemuk $(8,1 \%)$.

Tabel 5. Hubungan Kebiasaan Sarapan terhadap Status Gizi siswa SMP Negeri 5 Banyuwangi

\begin{tabular}{|c|c|c|c|c|c|c|c|c|c|c|}
\hline \multirow{3}{*}{ Kebiasaan Sarapan } & \multicolumn{10}{|c|}{ Status gizi } \\
\hline & \multicolumn{2}{|c|}{ Sangat kurus } & \multicolumn{2}{|c|}{ Kurus } & \multicolumn{2}{|c|}{ Normal } & \multicolumn{2}{|c|}{ Gemuk } & \multicolumn{2}{|c|}{ Obesitas } \\
\hline & $\mathbf{n}$ & $\%$ & $n$ & $\%$ & $n$ & $\%$ & $n$ & $\%$ & $n$ & $\%$ \\
\hline Kurang & 0 & 0,0 & 2 & 5,4 & 1 & 2,7 & 0 & 0,0 & 0 & 0,0 \\
\hline Baik & 1 & 2,7 & 3 & 8,1 & 26 & 70,3 & 3 & 8,1 & 1 & 2,7 \\
\hline Total & 1 & 2,7 & 5 & 13,5 & 27 & 73,0 & 3 & 8,1 & 1 & 2,7 \\
\hline
\end{tabular}

Penelitian ini juga menemukan bahwa sebagian siswa yang memiliki kebiasaan sarapan yang baik namun mempunyai status gizi yang sangat kurus $(2,7 \%)$, dan obesitas (2,7\%).Analisis statistik dengan uji regresi yang menunjukkan bahwa hubungan antara kebiasaan sarapan terhadap status gizi siswa $(p=0,049<$ $0,05)$. Maka dapat disimpulkan bahwa ada hubungan yang bermakna (signifikan) variabel kebiasaan sarapan dengan variabel status gizi siswa SMP Negeri 5 Banyuwangi

Dengan demikian dapat disimpulkan bahwa siswa yang terbiasa sarapan dengan baik menjadi salah satu faktor pendukung status gizi siswa tersebut. Maka dengan adanya sikap terbiasa sarapan dengan baik dapat memenuhi kebutuhan gizi dan mempertahankan status gizi menjadi ideal sesuai dengan berat badan dan kelompok usia. Faktor lain yang tak kalah penting dalam kontribusi mempertahankan status gizi adalah konsumsi makanan seimbang dan status kesehatan. Sebaiknya kebiasaan sarapan dengan makanan yang seimbang perlu terus diperhatikan terutama pada saat di rumah. Orang tua atau wali siswa diharapkan dapat mengerti dan memahami pentingnya kebiasaan sarapan dalam memenuhi kebutuhan gizi siswa pada usia remaja. Hasil penelitian ini relevan dengan penelitian Sarma Eko Natalia Sinaga (2016) yang menunjukkan bahwa variabel yang paling berpengaruh terhadap peningkatan status gizi pada siswa SMP Mardi Yuana Rangkasbitung adalah kebiasaan sarapan. ${ }^{15}$

\section{KESIMPULAN}

Kebiasaan sarapan siswa didominasi dengan kategori baik sebesar $91,9 \%$. Status gizi pada siswa didominasi dengan kategori normal sebesar $72,9 \%$. Terdapat hubungan antara kebiasaan sarapan dengan status gizi siswa SMP Negeri 5 Banyuwangi $(p=0,049<$ $0,05)$.

\section{ACKNOWLEDGEMENT}

Peneliti mengucapkan terimakasih kepada SMP Negeri 5 Banyuwangi yang telah memberikan izin untuk dapat terlaksananya penelitian, peneliti juga mengucapkan terimakasih kepada kepala sekolah SMP Negeri 5 Banyuwangi, responden, guru-guru, serta teman-teman yang telah membantu terlaksananya penelitian ini.

\section{REFERENSI}

1. Badan Penelitian dan Pengembangan Kesehatan Kementrian Kesehatan Republik Indonesia. Hasil Utama Riset Kesehatan Dasar Tahun 2018. Kementrian Kesehatan Republik Indonesia (2018). doi:1 Desember 2013

2. Dinas Kesehatan Propinsi JawaTimur. Profil Kesehatan Provinsi Jawa Timur 2017. Dinas Kesehatan Propinsi JawaTimur (2017).

3. Aprilia, A. Obesitas pada Anak Sekolah Dasar. Majority 4, 45-48 (2015).

4. Hardinsyah., Aries, M. Jenis Pangan Sarapan Dan Perannya Dalam Asupan Gizi Harian Anak Usia 6-12 Tahun Di Indonesia. J. Gizi dan Pangan 7, 89-96 (2012).

5. Hardiansyah, MS, D. Ilmu Gizi Teori dan Aplikasi. Gizi Bayi dan Balita (2017). doi:10.1111/j.16000897.2004.00224.x
6. Kral TV1, Whiteford LM, Heo M, F. M. Effects of eating breakfast compared with skipping breakfast on ratings of appetite and intake at subsequent meals in 8- to 10 -y-old children. Am. J. Clin. Nutr. 93, 284-91 (2017).

7. Arikunto, S. Prosedur Penelitian: Suatu Pendekatan Praktik. (PT Rineka Cipta : Jakarta., 2010, 2010).

8. Novitasari, A. Hubungan Antara Karakteristik, Pengetahuan, Sikap dan Faktor Lingkungan terhadap Perilaku Makan berdasarkan Pedoman Umum Gizi Seimbang (PUGS) pada Atlet Siswa di Gelora Bung Karno Senayan Jakarta Tahun 2009. (Universitas Indonesia, 2019).

9. Budiman, R. A. Kapita Selekta Kuesioner Pengetahuan dan Sikap dalam Penelitian Kesehatan. (Salemba Medika, 2013). 
10. Supariasa, I Dewa Nyoman., Bakri, Bachyar., Fajar, Ibnu., dan Ester, M. Penilaian Status Gizi. (EGC).

11. Arumsari, I. Hubungan Ketersediaan Sarapan dan Faktor Lainnya dengan Pola Sarapan Siswa/i SMA Terpilih di Kabupaten Tangerang Tahun 2014. (Universitas Indonesia, 2014).

12. Badan Pusat Statistik RI. Pengeluaran untuk Konsumsi Pemduduk Indonesia: Berdasarkan
Hasil Susenas Maret 2018.

13. Furkon, L. A. Ilmu Kesehatan dan Gizi. (Universitas Terbuka, 2014).

14. Sonia, T. \& Larega, P. Pengaruh Sarapan Terhadap Tingkat Konsentrasi pada Remaja. J Major. 4, 115-21 (2015).

15. Sinaga, S. E. N. Peningkatan Status Gizi pada Siswa SMP Mardi Yuana Rangkasbitung. J. Sk. Keperawatan 2, 70-76 (2016). 